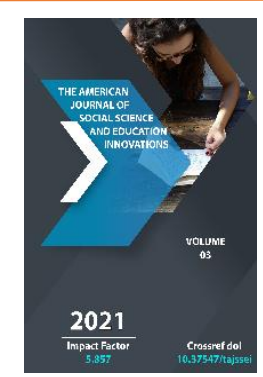

Journal Website: http://usajournalshub.c om/index,php/tajssei

Copyright: Original content from this work may be used under the terms of the creative commons attributes 4.0 licence.

\section{Technologies for Improving the Composition of Students in the System of Higher Pedagogical Education}

\author{
Botir Boltabayevich Baimetov \\ Professor, Chirchik State Pedagogical Institute, Tashkent Region, Uzbekistan
}

Bobur Abdugani Ogli Nabiyev

Master Student, Namangan State University, Department Of Fine Arts, Uzbekistan

\title{
ABSTRACT
}

The article examines the history of its origin, the originality of the composition in the creation of works of fine art, the necessary elements of the composition, shades, light and color solutions, as well as its attractiveness, the formation of lines and spots.

\section{KEYWORDS}

Composition, color, hue, color gamut, artistic creation.

\section{INTRODUCTION}

The purpose of studying the foundations of composition in the system of higher pedagogical education is to direct students to creativity in the process of practical training and the formation of work on independent visual arts. In addition to studying the heritage and experience of ancient masters of fine arts, any artist also learns the laws and methods of composition of a work of art that have a profound effect on the viewer.

In practice, the necessary elements of the composition, shade-light, color solution and its attractiveness, stylistic conditions, the 
formation of a series of lines, color spots, the relationship of perspective changes in the ratio defined by large and small dimensions, the viewing angle serves as a tool to reveal the content of the joint work.

Examples of structure and types of composition can be found in several works of Western and Eastern schools of fine arts and their creators. In the study of compositional types it is recommended to study not only realistic color-image, but also the composition of monumental works, the types of applied art, the composition of the composition without perspective, representing the level of painting. At the same time, the creators can imagine the natural world, the underwater world, the random events in nature, which enrich the imagination, and use them in the solution of the picture.

In the creation of a painting, it is necessary to study methodologically the national features of the rights, the landscape features of the clothes that belong there. The direct connection of painting with architecture, theatrical sculpture, music, literature and poetry enriches the content of the composition. Comprehensive in-depth study of composition requires a certain amount of personal work experience, skill and in-depth understanding. It enriches the art society of different periods with a new form, a new advanced concept and adds a special content. With the growth opportunities of society, the growth of perception, the ideas of life that have always been outdated in the art world, there is a struggle between stagnation and new currents.

\section{THE MAIN FINDINGS AND RESULTS}

The word composition comes from the Latin "composition"- to compare the pieces of objects, to place them in a certain order, to create according to the idea, to describe, to compose. It is not enough for a person to have the ability to be creative. The creator is not indifferent to life and the environment, the historical event in society changes in nature evoke in him the idea of expression. The artist finds a style of his own way, summarizing the impressions he sees along with an in-depth study of life. The artist must always be honest and express the truth. The artist is distinguished by his philosophical outlook, life experience, level of knowledge, mobility, personal image method used in the creative work.

Therefore, it is not difficult to know to which artist each work belongs. Examples are I. Repin, V. Surikov, P. Benkov and R. Akhmedovs works can be shown. They differ from each other in method. The creation of a work of art is the result of deep expression of emotions, as well as inspiration, hard work, professionalism, knowing this spiritual life well. The process of creating a work of art is unique to each artist its process is different and is performed in a colorful way. Many experiments are a process of creative research, observing nature, the environment, expressing the main factors, creating a sketch copy on the basis of sketches.

Whether a work of art is in the genre of still life, portrait, landscape, or everyday life, it requires the creation of a sketch solution in the pen, with a deep sense of composition. At the same time, the artist (black-and-white, light-dark in the sketch) performs the relationship of color and color, feeling the small details of the picture. The creator must observe daily life and events in the past and analyze its pros and cons. While one work of art was the impetus for the artist to create a work in a new historical genre, the second is to think, imagine 
use creative skills with a good understanding of the impressions of the past, the spiritual life.

The study of composition in the art and graphic faculties of pedagogical universities is an important factor in the formation of teaching activities, along with the development of creative abilities of students.

The composition is based on all types of art: literature, theater, cinema, music, fine and applied arts, architecture, etc.

Composition appeared as a subject after pencil and painting, and now the composition course is included in the curricula of higher education professions.

In the system of higher pedagogical education, the science of composition, along with the development of students' creative abilities, teaches the laws of composition, rules and methods of correct expression of truth.

In the fine arts, composition is created by visual means such as pencil, shadow-light, color, air, and line perspective. The composition course is of great importance for students to think figuratively in their independent creative and pedagogical activities.

The subject of composition consists of conversations, lectures and practical classes, in which the basic principles, methods and tools of composition are sufficiently studied by students in the course of practical classes and conversations.

As a subject of composition, specialized disciplines such as sculpture, architecture, graphics, pencil, painting, art history are inextricably linked.

In pencil and painting, the artist directly addresses the basics of composition, without knowing its rules, does not understand the essence of composition, pencil, painting. Therefore, it is recommended to study the science of composition as the most complex and important subject in the training of artiststeachers.

The laws and rules of composition in the fine arts have been formed since the time of primitive human development. However, while primitive people observed life with the mind, the sense of composition is very loosely developed. We can see such a situation in that the human body and animal forms are described randomly separately.

Artists of the ancient world began to apply the concepts of symmetry and rhythm in the structure of plants, leaves and flowers created by nature, in the sequence of the seasons, in their creative works, in composition. This is why the ancient Greeks made effective use of rhythm and symmetry in relief, fronton compositions. Until the Renaissance, he did not create any theoretical manual on the science of composition.

The Renaissance brought great art scholars to humanity. Artists of that period wrote valuable thoughts and conclusions about the composition in their memoirs and scientific articles.

Representatives of the early Renaissance, Djotto and Mazachcho, exemplified in their works that they were knowledgeable in the science of composition, applying the laws of perspective, plastic anatomy, in practice. High Renaissance artists connected different types of art with each other and developed his theory on a scientific basis. 
With the help of perspective, they were able to accurately depict the image of depth, distance in the picture.

Summarizing the ideological structure, style of color solution, practical experience of the works of prominent artists as a result of many years of observation and analysis, Alberti wrote "Three books on color imagery" scientific theoretical heritage. In their articles, Leonardo da Vinci and Alberti paid special attention to dynamic and static situations in their works of art. French artist E. Delacrua in his scientific articles Leonardo da Vinci, A. Dyurer, P. Rubens continued by expanding his compositional tracts and giving them deeper meanings.

We see in the form of Leonardo da Vinci, in the form of a fair man who could easily do anything, the ability that scientists have repeatedly witnessed the coming to earth of the beauty and ability bestowed on him by God under the influence of the light of the stars.

Leonardo, the son of Mr. Perot who lived Vinca, possessed such divine power that he spent several months studying mathematics, perfecting his skills, performing lyric music. Still, his main interest was painting and sculpting.

God-given incomparable intelligence, a strong memory, a great scientist amazes with his drawing, amazes with the power of thought. In Milan, he created a beautiful work for the Dominican brothers called The Secret Night. He portrayed the saints as glorious, adding beauty to their faces. Only Isusni had no divine power to describe his face, and he could not finish his life. Leonardo studied human anatomy in depth, based on the teachings of Galena, began to carefully draw the skeletal muscles of corpses in pencil and red pencil, and created a book of images of human anatomy. He also created a book on the anatomy of the bones of horses. Many of these anatomical lines have come down to us, along with Leonardo's selfportraits..

For Leonardo Francesco del Giocondo, he worked on a portrait to his wife, Lisa, for 4 years, but still failed to complete the portrait. In the portrait, all the beautiful qualities of a woman are depicted in the form of a living human gaze, up to the lashes of her shining wet eyes.

The existence of such crown works in the fine arts still amazes people with the fact that they belong to the pen of the most talented, intelligent scientist and artist in the world. Composition began to take shape as an educational science in the late 16th century. This can be seen from the reports of Methodists such as V. Neleng, S. Vasilev on the teaching system after their visit to France. In 1882, the famous educator-painter Violie Le Duca translated the book "History of the Historian" into Russian. This book is presented in the form of an interview based on personal work experience and a methodology of teaching fine arts. In the "Sochinenie" section of this book, the fantasy, the perspective, is taught to get acquainted with certain laws. The author of the first methodical protocol on the issues of composition in the fine arts is an American pedagogue-artist A. Doudir. In this tutorial, special attention was paid to the correct placement of different shapes, colors on paper and fabric in the image, the size and format of the paper. The emergence of a new stream of impressionism in the fine arts was a means of renewal in painting, serving as a catalyst for the further development of art. The Impressionists enriched the color palette. In the early $X X$, various artistic currents began to 
emerge in Western Europe and Russia: futurism, cubism, expressionism, dadaism, surrealism, among others..

In XVIII Russian fine arts, the founders of the school of realistic art were A.P. Losenko, G.I. They are Ugryumovs. A.Ivanov, A.Egorov, V.Shebuev, A.Venetsiyanov, K.Bryulov, graduates of the St. Petersburg Academy of Arts in Russia, in their creative and pedagogical activities paid more attention to the problems of composition and raised the fine arts to a new level. The regular establishment of the teaching of special subjects at the St. Petersburg Academy of Arts, founded in 1757, had an impact on the development of Russian fine arts.

Well-known artist and educator A.P. Losenko in his work worked creatively on the issues of composition. He stressed that all visual aids should be focused on the idea and content of the work.

Losenko in his time realized the renewal of the method of academic education and developed a new methodology. The Academy teaching theory he created lasted until the middle of the 19th century. During the time of Losenko, the fame and prestige of the Russian Academy of Arts spread around the world.

A.P. Losenko was a master of high-level composition. This can be seen in the painting "Vladimir before Rogneda". In the historical genre class that Losenko taught, much attention was paid to the issues of painting structure.

The great representative of realistic art, I.E. Repin made an important contribution to the theoretical and practical development of the composition. Also with all the new innovative tools in the historical genre. V. Surikov influenced Russian artists. He paid special attention to the execution of the composition sketch. When the subject he imagined was revived in the artist's imagination, he immediately took a pencil, charcoal, and a brush and began to sketch. Especially for the painting "Boyarina Morozova", he made dozens and hundreds of pencils and sketches. He carefully studied the historical events that took place on the subject. At the end of the XIX and the beginning of the XX century in the Russian art and education system, along with the progressive direction, under the influence of reactionary forces, a new movement imitating bourgeois philosophy - "Novizna" began to appear.

Great educator painter D.N. Kardovsky fought uncompromisingly against this and defended it from a position of realism. D. Kardovsky also $P$. Like Chistyakov, he was one of the most respected educators and artists in the fine arts. V. Efanov, D. Shmarinov Russian artists, such as Shmarinov, were well educated in his workshop.

\section{CONCLUSION}

In conclusion, it can be said that the science of composition has undergone many years of development from the distant past to the present. Over the years, an excellent learning system of pencil and composition was formed. Composition is a means of figurative representation of life events, which set the principles for the transition from students to sketches in a certain format, from simple to complex. Later, the theory of composition, the basic principles of teaching methods in practice were developed. Contrast, vertical, horizontal, diagonal symmetry, asymmetry, circle, triangle, balance, rhythm integrity, dynamic, we can see image styles such as static state, 
The American Journal of Social Science and Education Innovations (ISSN - 2689-100x)

light, color color, construction point, horizon, composition plan, majesty, decorativeness.

\section{REFERENCES}

1. B.B. Baymetov, ST Sobirov, U Sh Ismatov. PROBLEMS OF PROFESSIONAL AND PEDAGOGICAL TRAINING OF FINE ART TEACHERS.2019. Журнал Bulletin of Science. Том 1,Номер 7, страницы 6366.

2. B.B. Baymetov, $\mathrm{N}$ Kh Talipov. METHODOLOGICAL SEQUENCE OF WORKING ON A PAINTING PORTRAIT IN A PEDAGOGICAL UNIVERSITY. 2016. Журнал Scientific discussion: issues of pedagogy and psychology, (4-1) Том 4650.

3. B.B. Baymetov, Ulfat Shuxratovich Ismatov PEDAGOGIKA OLIY TA'LIM MUASSASALARIDA TALABALARINI BOSH NAMUNASINI TASVIRLASHGA O'RGATISH ORQALI TYEXNIK MAHORATLARINI

TAKOMILLASHTIRISH Science and education journal. 2020/8. Страницы476-485

4. Botir Boltabaevich Baymetov. Technologies Of Moving Images of PeopleFrom Different Views In Fine Arts Lessons. 2021/1/31.Журнал

5. The American Journal of Social Science and Education Innovations. Том 3.Номер 01. Страницы 463-468

6. Botir Boltabaevich Baymetov. Art Of Modern Uzbekistan: The History Of Its Development During The Years Of Independence. Дата публикации

7. 2020/10 Журнал The American Journal of Social Science and Education
Innovations Том 2 Номер 10-2020 Страницы 125-132

8. Baymetov Botir Boltaboevich. Methods of Portraiture in the Process of Making Sketches and Drawings of the Human Face in Higher Pedagogical Education. Дата публикации 2020 Журнал International Journal of Psychosocial Rehabilitation Том 24 Номер 05 Страницы 6408-6415.

9. Botir Boltabayevich Baymetov. Technologies Of Moving Images of People From Different Views In Fine Arts Lessons. The American Journal of Social Science and Education Innovations. 2021/1. The American Journal of Social Science and Education Innovations (ISSN - 2689-100x) Published: January 31, 2021.том 3.номер 1. Страницы 463-468.

10. B.B. Baymetov. Inson qomatining turli ko'rinish va holatlaridan qisqa muddatli tasvirlaridan bajarish myetodikasi "Science and Education" Scientific Journal January 2021 / Volume 2 Issue 1. 357-365.

11. B.B. Baymetov, XX Muratov. Tasviriy san'atdan amaliy mashg'ulotlarida talabalarning tasvirlash mahoratlarini takomillashtirish texnologiyalari. Science and Education, 2021. 349-356.

12. Botir Boltabaevich Baymetov Xusan Xolmuratovich Muratov. Methods Of Teaching Students To Do Sketches In Independent Learning.2020/12. The American Journal of Social Science and Education Innovations. 2. Номер 12. Страницы 8-13

13. Ulfat Shuxratovich Ismatov Botir Boltabaevich Baymetov. Pedagogika oliy ta'lim muassasalarida talabalarini bosh namunasini tasvirlashga o'rgatish 
orqali tyexnik mahoratlarini takomillashtirish. 2020/11. "Science and Education" Scientific Journal November 2020 / Volume 1 Issue 8 Страницы 476-484

14. Laylo Mirsoatova Botir Boltabayevich Baymetov. Oliy pyedagogik ta'limda inson qomatini tasvirlashning nazariyasi va myetodikasi.2020/11 "Science and Education" Scientific Journal November 2020 / Volume 1 Issue 8. Страницы 467-475

15. Botir Boltabaevich Baymetov, Ulfat Shuhratovich Ismatov. Development of competencies of future fine art teachers in description of nature in graphic materials. 2020. ACADEMICIA: An International Multidisciplinary Research Journal.том 10.Номер 11.Страницы 864-871.

16. Botir Boltabaevich Baymetov. Creativity Of The Outstanding ArtistMiniaturist Kamaleddin Behzad (14551536). INTERNATIONAL SCIENTIFIC AND CURRENT RESEARCH CONFERENCES "SCIENCE AND INNOVATION IN THE XXI CENTURY: CRUCIAL ISSUES, DISCOVERIES AND ACHIEVEMENTS" Doi https://doi.org/10.37547/iscrc-intconf 03 2021/2/19.Pages: 67-71. Hungary, Europe

17. Botir Boltabaevich Baymetov. oliy pyedagogik ta'limda bo'lajak tasviriy san'at o'qituvchilarining ijodiy qobiliyatlarini shakllantirishning ba'zi masalalari. academic research in educational sciences volume 2 | issue 1 | 2021. 277-283 бетлар.

18. B.B. Baymetov, XX Muratov. Tasviriy san'atdan amaliy mashg'ulotlarida talabalarning tasvirlash mahoratlarini takomillashtirish texnologiyalari. Science and Education, 2021. 349-354 бетлар.

19. Мукаддам Тожикузи кизи Хамрокулова, Рашид Неъматович Зульфиев, Ботир Болтабаевич Байметов. Теория и практика преподавания академического рисунка в подготовке будущего художника педагога. Science and education scientific journal. 2020/12.Том 1. Номер 9. стр 364-372.

20. Botir Boltabaevich Baymetov. Art Of Modern Uzbekistan: The History Of Its Development During The Years of Independence. The American Journal of Social Science and Education Innovations. 2020/10. 125-132.

21. B.B. Boltaboevich. Methods of portraiture in the process of making sketches and drawings of the human face in higher pedagogical education. International Journal of Psychosocial Rehabilitation, 2020. Том 24. Номер 5.Страницы 6408-6415.

22. B.B. Baymetov. Inson qomatining turli ko'rinish va holatlaridan qisqa muddatli tasvirlaridan bajarish myetodikasi. "Science and Education" Scientific Journal January 2021 / Volume 2 Issue. 357-365 